\title{
Familial forms of disorders of sex development may be common if infertility is considered a comorbidity
}

Raja Brauner ${ }^{1 *}$, Flavia Picard-Dieval ${ }^{1}$, Henri Lottmann², Sébastien Rouget ${ }^{1}$, Joelle Bignon-Topalovic ${ }^{3}$, Anu Bashamboo ${ }^{3}$ and Ken McElreavey ${ }^{3}$

\begin{abstract}
Background: Families with 46,XY Disorders of Sex Development (DSD) have been reported, but they are considered to be exceptionally rare, with the exception of the familial forms of disorders affecting androgen synthesis or action. The families of some patients with anorchia may include individuals with 46,XY gonadal dysgenesis. We therefore analysed a large series of patients with 46,XY DSD or anorchia for the occurrence in their family of one of these phenotypes and/or ovarian insufficiency and/or infertility and/or cryptorchidism.

Methods: A retrospective study chart review was performed for 114 patients with 46,XY DSD and 26 patients with $46, X Y$ bilateral anorchia examined at a single institution over a 33 year period.

Results: Of the 140 patients, 25 probands with DSD belonged to 21 families and 7 with anorchia belonged to 7 families. Familial forms represent 22\% (25/114) of the 46,XY DSD and 27\% (7/26) of the anorchia cases. No case had disorders affecting androgen synthesis or action or 5 a-reductase deficiency. The presenting symptom was genital ambiguity $(n=12)$, hypospadias $(n=11)$ or discordance between $46, X Y$ karyotyping performed in utero to exclude trisomy and female external genitalia $(n=2)$ or anorchia $(n=7)$. Other familial affected individuals presented with DSD and/or premature menopause (4 families) or male infertility (4 families) and/or cryptorchidism. In four families mutations were identified in the genes SRY, NR5A1, GATA4 and FOG2/ZFPM2. Surgery discovered dysgerminoma or gonadoblastoma in two cases with gonadal dysgenesis.

Conclusions: This study reveals a surprisingly high frequency of familial forms of 46,XY DSD and anorchia when premature menopause or male factor infertility are included. It also demonstrates the variability of the expression of the phenotype within the families. It highlights the need to the physician to take a full family history including fertility status. This could be important to identify familial cases, understand modes of transmission of the phenotype and eventually understand the genetic factors that are involved.
\end{abstract}

Keywords: 46,XY disorders of sex development, Anorchia, Cryptorchidism, DSD, Infertility, Hypospadias, Premature menopause, Premature ovarian insufficiency

\footnotetext{
*Correspondence: raja.brauner@wanadoo.fr

${ }^{1}$ Fondation Ophtalmologique Adolphe de Rothschild and Université Paris

Descartes, Paris, France

Full list of author information is available at the end of the article
} International License (http://creativecommons.org/licenses/by/4.0/), which permits unrestricted use, distribution, and reproduction in any medium, provided you give appropriate credit to the original author(s) and the source, provide a link to the Creative Commons license, and indicate if changes were made. The Creative Commons Public Domain Dedication waiver (http://creativecommons.org/publicdomain/zero/1.0/) applies to the data made available in this article, unless otherwise stated. 


\section{Background}

The term "disorders of sex development" (DSD) has been defined as "congenital conditions in which the development of chromosomal, gonadal, or anatomical sex is atypical" [1]. DSD constitutes a spectrum of disorders that affect the genito-urinary tract and the endocrinereproductive system. Anorchia, or embryonic testicular regression (vanishing testis syndrome), is defined as the absence of testes in a 46,XY individual with a male phenotype [2]. It affects one in 20,000 male births [3] and occurs in 1/ 177 cases of cryptorchidism [4]. Although some patients with anorchia present with genital ambiguity [5] or microphallus [6], most have a normal phenotype. The differentiation of the male genital tract and external genitalia is dependent on anti-Müllerian hormone (AMH) and testosterone, suggesting that functional testes were present but disappeared in utero in these cases. The families of some patients with anorchia may include individuals with 46,XY gonadal dysgenesis. This has led to the hypothesis that anorchia is part of the clinical spectrum of 46,XY gonadal dysgenesis [7]. We and other investigators have observed a variable expression of the clinical phenotypes between family members carrying the same pathogenic mutation (NR5A1, GATA4 and FOG2/ZFPM2) [8-10]. Families with $46, \mathrm{XY}$ DSD have been reported, but they are considered to be exceptionally rare, with the exception of the familial forms of partial or complete androgen insensitivity [11].

We analyzed data obtained from 114 cases of 46,XY DSD and 26 cases of anorchia for the occurrence in their family of one of these phenotypes and/or ovarian insufficiency and/or infertility and/or cryptorchidism. Our data are based on the clinical experience of one pediatric endocrinologist and reveal a surprisingly high frequency of familial forms when premature menopause or male infertility is included.

\section{Methods \\ Patients}

A retrospective study chart review was performed for 140 patients evaluated by a senior pediatric endocrinologist ( $\mathrm{R}$ Brauner) in a university pediatric hospital at a single institution between 1981 and 2014 (33 years). This patient population comprised 114 patients with 46,XY DSD and 26 patients with 46,XY bilateral anorchia. Of these 114 patients, 10 had disorders affecting androgen synthesis ( 2 patients with $3-\beta$ hydroxysteroid dehydrogenase deficiency, 1 patient with CYP11A1 deficiency and 3 patients with $5 \alpha$-reductase deficiency) or action ( 4 patients with partial androgen insensitivity). None of these patients presented with the familial form. This conclusion was based on self-reported family history and on clinical assessment of the sibs of the proband.

Among the 32 familial cases included in the present study, 12 were previously reported as anorchia $(n=7)$
[12], gonadal dysgenesis $(n=4)$ [13] and/or as the first description of the mutation $(n=3)$ [8-10].

\section{Methods}

The Ethical Review Committee (Comité de Protection des Personnes, Ile de France IV) approved this study (IRB ${ }^{\circ}$ 00003835). The following parameters were extracted from the medical report: consanguinity, family history relevant to gonadal anomalies, infertility or precocious menopause (arrest of menstruations before 40 years [14]), length and weight at birth, comorbidity or malformations, age and symptoms at first evaluation. Clinical examination included an evaluation of the dimensions of the genital tubercle and the position of the meatus (penoscrotal, midshaft or glandular) and palpation of the labio-scrotal and inguinal areas for the presence and consistency of the gonads. Internal genitalia were evaluated by pelvic ultrasound examination (cases 3-8, 11, 17, 18, 20, and 23), together with magnetic resonance imaging (MRI) in one patient (case 6) because the uterus was not observed. Seven patients underwent genitography (cases 1, 3, 7, 8, 11, 17, and 23). Ultrasound examination was carried out to assess kidney malformations (cases 4, 8, 9-12, 14, 16, 17, 18, and 32).

Gonadal dysgenesis was defined by the presence of Müllerian structures at genitography and/or surgery and/or histological examination. The patients classified as having hypospadias had a normal penis length (greater than $30 \mathrm{~mm},-2 \mathrm{SD}$ ) [15] and bilaterally or unilaterally palpable inguinal or intrascrotal gonads. Anorchia was defined as the absence of testicular tissue at surgery or by the presence of a small nodule of residual fibrous tissue in a 46,XY individual with a male phenotype.

Nine patients were given testosterone heptylate (3 or $4 \times 100 \mathrm{mg} / \mathrm{m} 2$ given IM every 15 days) in the neonatal period before the sex assignment and/or before the genitoplasty.

The endocrine evaluation was performed before surgery. In the patients with DSD, congenital adrenal hyperplasia (normal basal plasma concentrations of $17-\mathrm{OH}$ progesterone in all cases) or insufficiency (normal basal plasma concentrations of adrenocorticotropin hormone and cortisol in cases $3,8,10,11,13,14,17,20,22$, and 23) or a defect of testosterone biosynthesis were excluded. Partial androgen insensitivity was excluded by the clinicalbiological data (low plasma testosterone concentrations during the first months [16] and an increase in genital tubercle after testosterone administration) and by the absence of mutation in exons 1 and 2-8 of the receptor gene in cases 1, 2, 4, 11, 16 and 23-25 (exon 1 not evaluated in case 23 ). $5 \alpha$-reductase deficiency was excluded by measuring the testosterone-to-dihydrotestosterone ratio in the basal state (cases 1, 2, 3, 10, 11, 12, 13, and 25) or after stimulation with human chorionic gonadotropin (hCG, cases $6,7,17,20$, and 23) and by the absence of mutation 
in the corresponding gene in cases 11, 16 and 25. Leydig cell function was evaluated by measuring the basal plasma testosterone concentration and after stimulation with hCG (3 or $7 \times 1500 \mathrm{IU}, n=9$ ) with samples taken the day after the last injection. The hCG test was not performed on patients with a basal plasma testosterone concentration > $2 \mathrm{ng} / \mathrm{mL}$ (except in case 4). Plasma testosterone was measured by using RIA after extraction with Orion reagents (Cis biointernational, Gif-sur-Yvette, France). The sensitivity was $0.07 \mathrm{ng} / \mathrm{mL}$. Plasma hormone concentrations were measured using different immuno-assays during the study period. Each new assay method for a given hormone was always cross-correlated with the previous method to ensure that the results are comparable throughout the entire study period. Plasma concentrations were measured for AMH (except in cases 7, 17, 20, 28 and 32) and inhibin B (except in cases 4, 7, 8, 17, 20, 23, 28, 29 and 32) [17-19]. Plasma AMH was measured using the AMH/Müllerian-inhibiting substance ELISA kit (Immunotech-Beckman, Marseille, France). Plasma inhibin B was measured by ELISA using Oxford Bio-Innovation reagents (Diagnostic Systems Laboratories-France, Cergy-Pontoise, France). Conventional histologic examination of the gonads was performed after gonadectomy (cases 6, 17, and 20) or testicular biopsy (case 25 at 24 years of age).

\section{Genetic analyses}

For each patient, cytogenetic analysis was performed on peripheral blood leukocytes. The chromosome complement was determined by examining 40-50 metaphases from each patient. The SRY, NR5A1, GATA4, FOG2, INSL3, LGR8 and MAP3K1 genes were sequenced as previously described [20-25] in all patients with DSD until the genetic diagnosis was determined (except in case 24, for which the brother, case 16, had been sequenced). In the patients with anorchia, the complete open reading frames of SRY, NR5A1, INSL3, MAMLD1 and the T222P variant for $L G R 8$ were sequenced as previously described [20-25].

\section{Results}

Of the 140 patients, 25 probands with DSD belonged to 21 families and 7 with anorchia belonged to 7 families. Familial forms represent 22\% (25/114) of the 46,XY DSD and $27 \%(7 / 26)$ of the anorchia cases. The patients with familial form were classified according to the presenting symptom of the index case in two groups: 46,XY DSD with a female phenotype, genital ambiguity or hypospadias (cases 1 to 25) or 46,XY anorchia (cases 26 to 32, Fig. 1).

\section{6,XY DSD}

Eight patients had comorbidities or somatic anomalies, including two cases with ectodermal dysplasia (cases 6 and 20), one with a congenital cervical mass of $25 \times 20 \times 8$ $\mathrm{mm}$ containing epitheloid and/or gigantocellular granulomas (case 4), one with bilateral clinodactyly of the $5^{\text {th }}$ finger (case 17), three with retarded prenatal (case 13) or postnatal growth (cases 14 and 22) without defined etiology and one with bilateral vesico-ureteral reflux (case 15).

The gender of rearing was female in 4 patients with female presentation or Prader I to III due to gonadal dysgenesis (cases $5,6,17,20$ ), and male in 21 patients (Table 1 ). There was no change in the gender after this assignment. The first evaluation was made either prenatally $(n=2)$, before the age of 6 months $(n=11)$, between the age of 6 and 12 months $(n=3)$ or after one year of age $(n=9)$. The presenting symptom was genital ambiguity $(n=12)$, hypospadias $(n=11)$ or discordance between $46, \mathrm{XY}$ karyotyping performed in utero to exclude trisomy and female external genitalia (cases 5 and 6).

Among the patients evaluated during the first 6 months of life, 6 patients had basal plasma testosterone concentrations greater than $1 \mathrm{ng} / \mathrm{mL}$ and 7 patients had low concentrations of plasma testosterone (Table 2). Of these, two had gonadal dysgenesis (case 5 with a mutation in the SRY gene and case 6) and also had low or undetectable concentrations of inhibin B and $\mathrm{AMH}$. One had a mutation in the GATA4 gene (case 7) and one in NR5A1 gene (case 8). The 3 other patients with low testosterone concentrations are brothers (cases 2, 3, 11) and they had normal plasma inhibin $\mathrm{B}$ and $\mathrm{AMH}$ concentrations. Their maternal uncle (case 25) had a normal pubertal increase in testosterone and pubertal development but normal then low inhibin $B$ associated with azoospermia that was confirmed by testicular biopsy. After stimulation with hCG, the testosterone concentration was $>2 \mathrm{ng} / \mathrm{mL}$ in 2 of the 7 patients evaluated (cases 4 and 20). The basal plasma follicle stimulating hormone (FSH) concentration was increased ( $>9 \mathrm{IU} / \mathrm{L})$ in 2 patients (cases 6 and 17 with gonadal dysgenesis) and normal in the others who were in the prepubertal age range, except cases 24 and 25, which were pubertal. The plasma inhibin B concentrations were normal except in the cases with gonadal dysgenesis (cases 5 and 6) and in case 14 , which was not reevaluated. The plasma AMH concentrations were also decreased in cases 5 and 6 and 23, increased in cases 1 and 12, and normal in the others.

Müllerian structures were seen in the 4 cases with gonadal dysgenesis at ultrasound evaluation (cases 5 and 20), genitography (case 17) or MRI (case 6). This was confirmed at surgery in all cases, except in case 5 , in which no operation had been performed. Surgery discovered right dysgerminoma in case 6 and right gonadoblastoma in case 20.

\section{Anorchia}

No patient presented with somatic anomalies (Table 3). The mother of case 26 began menstruating at 12 years of age. She was operated on for scalenus syndrome. She had a previous medical pregnancy interruption at 20 weeks 


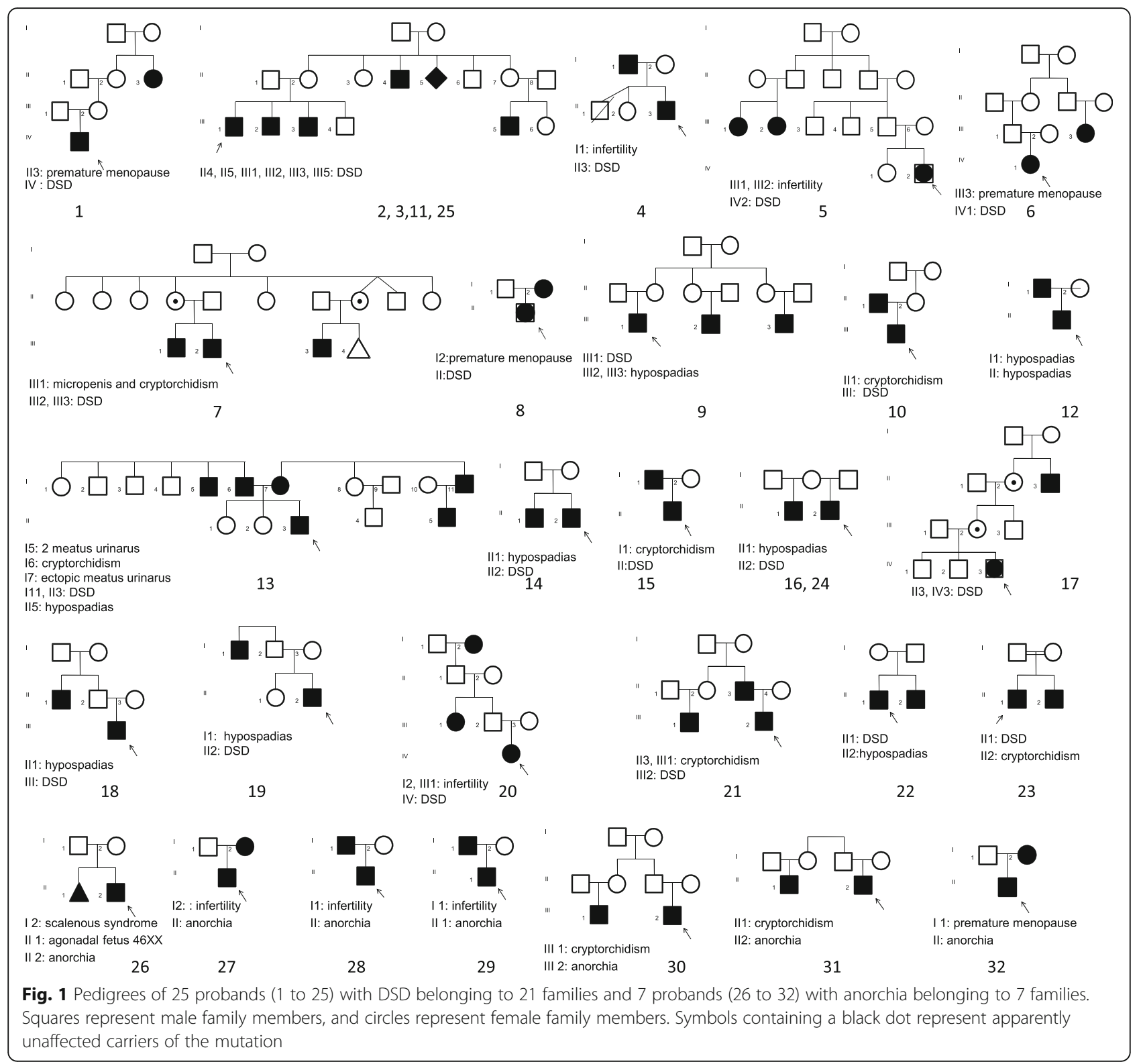

because of hygroma and anasarque. The female fetus had a 46,XX blood karyotype, intrauterine growth retardation, retrocervical edema, retrognathism, clinodactyly of the $5^{\text {th }}$ digit, agenesis of the $12^{\text {th }}$ pair of ribs, and ovaries with germ cells but no primary follicles. The mother of case 27 began menstruating at 9.5 years of age, then had irregular menstruation with increased basal plasma FSH concentrations and underwent 4 attempts at in vitro fertilizations before this pregnancy. After the proband was born, she underwent insemination, which led to an empty follicle. Her own mother experienced menopause at 50 years of age and had a hysterectomy for a fibroma. The father had a normal spermogram.

At the first evaluation, all patients had unpalpable testes and normal penis length and morphology, except case 26, which presented with micropenis. The basal plasma concentrations of inhibin B, AMH and testosterone were very low or undetectable in all of the patients evaluated. The plasma concentrations of FSH were increased, except in cases 26, 30 and 31. Surgery showed no testicular tissue (cases 26 and 30) or unilateral or bilateral residues in the others.

\section{Modes of inheritance and genetic analyses}

Figure 1 shows the pedigrees of the families. In addition to the genital anomalies, families reported premature menopause (cases 1, 6, 8, and 32) or infertility (cases 4, 5, 20, and 28). Assuming that DSD and infertility have the same genetic basis in these families, the mode of transmission of the phenotype in all families is suggestive of an autosomal 
Table 1 Clinical characteristics of 25 patients with familial DSD

\begin{tabular}{|c|c|c|c|c|c|c|c|c|c|c|}
\hline \multirow[t]{2}{*}{ Case } & \multirow[t]{2}{*}{ Sex } & \multirow[t]{2}{*}{$\begin{array}{l}\text { Age at first } \\
\text { evaluation }\end{array}$} & \multirow[t]{2}{*}{ Presentation } & \multirow[t]{2}{*}{ Prader } & \multirow[t]{2}{*}{$\begin{array}{l}\text { Localization of } \\
\text { the meatus }\end{array}$} & \multicolumn{2}{|c|}{$\begin{array}{l}\text { Genital tubercle } \\
(\mathrm{mm})\end{array}$} & \multirow[t]{2}{*}{$\begin{array}{l}\text { Testosterone } \\
\text { dose (mg) }\end{array}$} & \multicolumn{2}{|c|}{ Gonad } \\
\hline & & & & & & before & after & & Right & Left \\
\hline 1 & M & $1 d$ & genital ambiguity & IV & penoscrotal & $15 \times 7$ & $30 \times 12$ & $4 \times 25$ & s & $\mathrm{i}$ \\
\hline 2 & M & $1 \mathrm{~d}$ & genital ambiguity & IV & glandular & $20 \times 10$ & & $4 \times 50$ & s & s \\
\hline 3 & M & $3 d$ & genital ambiguity & IV & penoscrotal & $25 \times 10$ & & $4 \times 50$ & $\mathrm{np}$ & $\mathrm{np}$ \\
\hline 4 & M & $3 d$ & genital ambiguity & IV & penoscrotal & $20 \times 8$ & $30 \times 10$ & $4 \times 25$ & i & i \\
\hline $5^{\mathrm{a}}$ & $\mathrm{F}$ & $3 d$ & prenatal karyotype & 0 & normal & & & & $\mathrm{np}$ & $\mathrm{np}$ \\
\hline 6 & $\mathrm{~F}$ & $4 d$ & prenatal karyotype & । & normal & & & & $\mathrm{np}$ & $\mathrm{np}$ \\
\hline $7^{\mathrm{a}}$ & M & $7 d$ & genital ambiguity & IV & penoscrotal & 13 & $22 \times 15$ & $3 \times 30$ & $\mathrm{i}$ & $\mathrm{i}$ \\
\hline $8^{\mathrm{a}}$ & M & $21 d$ & genital ambiguity & III & penoscrotal & $15 \times 10$ & $30 \times 15$ & $4 \times 40$ & s & s \\
\hline 9 & M & $0.1 \mathrm{y}$ & hypospadias & IV & penoscrotal & $30 \times 25$ & & & s & s \\
\hline 10 & M & $0.1 y$ & hypospadias & IV & penoscrotal & $30 \times 10$ & & & s & s \\
\hline 11 & M & $0.1 y$ & genital ambiguity & IV & penoscrotal & $20 \times 10$ & $28 \times 10$ & $4 \times 37.5$ & s & s \\
\hline 12 & M & $0.3 y$ & hypospadias & IV & distal & $35 \times 15$ & & & s & s \\
\hline 13 & M & $0.4 y$ & genital ambiguity & IV & midshaft & $25 \times 10$ & & $3 \times 50$ & s & s \\
\hline 14 & M & $0.6 y$ & hypospadias & IV & penoscrotal & $40 \times 15$ & & & s & s \\
\hline 15 & M & $0.8 y$ & hypospadias & IV & penoscrotal & $35 \times 15$ & & $3 \times 50$ & i & i \\
\hline 16 & M & $0.9 y$ & hypospadias & IV & midshaft & $40 \times 20$ & & & s & s \\
\hline $17^{\mathrm{a}}$ & $\mathrm{F}$ & $1.5 \mathrm{y}$ & genital ambiguity & III & penoscrotal & $5 \times 5$ & & & $\mathrm{np}$ & $\mathrm{np}$ \\
\hline 18 & M & $1.8 \mathrm{y}$ & hypospadias & IV & glandular & $35 \times 10$ & & & $\mathrm{i}$ & s \\
\hline 19 & M & $3 y$ & hypospadias & V & midshaft & $45 \times 15$ & & & s & s \\
\hline 20 & $\mathrm{~F}$ & $3.5 \mathrm{y}$ & genital ambiguity & $\|$ & glandular & 18 & & & $\mathrm{i}$ & $\mathrm{np}$ \\
\hline 21 & M & $3.9 y$ & hypospadias & IV & glandular & $50 \times 15$ & & & i & s \\
\hline 22 & M & $7.6 \mathrm{y}$ & hypospadias & IV & glandular & $45 \times 15$ & & & s & s \\
\hline 23 & M & $10 y$ & hypospadias & V & penoscrotal & $40 \times 12$ & & & i & i \\
\hline 24 & M & $13.6 y$ & genital ambiguity & IV & penoscrotal & $75 \times 35$ & & & $\mathrm{np}$ & $\mathrm{np}$ \\
\hline 25 & M & $15 y$ & genital ambiguity & IV & midshaft & $65 \times 25$ & & & i & i \\
\hline
\end{tabular}

DSD disorders of sex development, $i$ inguinal, $s$ scrotal, $n p$ not palpable

${ }^{\mathrm{a}}$ Genetic mutations

Cases 2,3,11 are brothers and case 25 is their maternal uncle. Cases 16 and 24 have the same mother (see pedigree)

dominant inheritance with a high degree of incomplete penetrance. Some pedigrees (eg index case 9 and index case 17) are indicative of a sex-limited expression. Consanguinity was present in case 23 , in which the parents were first cousins. Mutations were identified in one patient with female external genitalia and $3 / 12$ patients with genital ambiguity (25\%) in the genes $S R Y$ (case 5), a heterozygous NR5A1 mutation (case 8) [8], heterozygous GATA4 (case 7) [9] and heterozygous FOG2/ZFPM2 mutation (case 17) [10]. The inheritance of the $S R Y$ mutation is unknown because the father's DNA was not available for study. However, he has two female cousins who were reported to be infertile. In each of the 3 other cases, the mother transmitted heterozygous mutation. The mother of case 8 , who carries the NR5A1 mutation, underwent premature menopause. The other mothers carrying mutations in GATA4 or FOG2 had apparently normal ovarian function (detailed in $[9,10])$. In case 17 , the heterozygous FOG2/ZFPM2 mutation was carried by the unaffected mother and grandmother suggesting that mutations in this gene are associated with a sex-limited phenotype.

All other patients with DSD were sequenced for the SRY, NR5A1, GATA4, FOG2, INSL3, LGR8 and MAP3K1 genes, and no pathogenic mutations were identified. All patients with anorchia were sequenced for SRY, NR5A1, INSL3, MAMLD1 and the T222P variant of LGR8 and no pathogenic mutations were identified.

\section{Discussion}

We report, for the first time, a large monocentric study of familial forms of 46,XY DSD. This study shows a high frequency of the familial forms compared to the sporadic forms seen over 33 years by the same pediatric 
Table 2 Hormonal levels and family history of 25 patients with familial DSD

\begin{tabular}{|c|c|c|c|c|c|c|c|c|}
\hline \multirow[t]{2}{*}{ Case } & \multirow[t]{2}{*}{ Age at assays } & \multicolumn{2}{|c|}{ Testosterone (ng/ml) } & \multirow{2}{*}{$\begin{array}{l}\text { LH basal } \\
(\mathrm{IU} / \mathrm{L})\end{array}$} & \multirow{2}{*}{$\begin{array}{l}\text { FSH basal } \\
(\mathrm{IU} / \mathrm{L})\end{array}$} & \multirow{2}{*}{$\begin{array}{l}\text { INHIBIN B } \\
(\mathrm{pg} / \mathrm{mL})\end{array}$} & \multirow[t]{2}{*}{$\mathrm{AMH}(\mathrm{pmol} / \mathrm{L})$} & \multirow[t]{2}{*}{ Parent (family history) } \\
\hline & & Before hCG & After hCG & & & & & \\
\hline 1 & $1 d$ & 2.7 & & $0.7^{b}$ & $<0.4^{\mathrm{b}}$ & $178^{b}$ & $2348^{b}$ & $\begin{array}{l}\text { mother (premature menopause ( } 27 \text { years) } \\
\text { in sister of his mother) }\end{array}$ \\
\hline 2 & $7 d$ & 0.3 & & 1.5 & $<0.4$ & 186 & 794 & mother (DSD in brother, sister and nephew) \\
\hline 3 & $3 d$ & 0.2 & & $<0.4$ & $<0.4$ & $>400$ & $>600$ & mother (brother of case 2) \\
\hline 4 & $3 d$ & 4 & 5.5 & $0.8^{b}$ & $1.3^{b}$ & ND & $614^{b}$ & father (secondary infertility) \\
\hline $5^{a}$ & $3 d$ & 0.1 & & 0.1 & 0.4 & $<3$ & $<1$ & father (infertility in 2 female cousins) \\
\hline 6 & $4 d$ & $<0.07$ & $<0.07$ & 3.3 & 11 & $<10^{\mathrm{b}}$ & $1^{\mathrm{b}}$ & father (premature menopause (38 years) in cousin) \\
\hline $7^{\mathrm{a}}$ & $14 d$ & 0.1 & 0.25 & 0.2 & 3.9 & ND & & $\begin{array}{l}\text { mother (DSD in one nephew, congenital } \\
\text { heart disease; brother with micropenis } \\
\text { and cryptorchidism) }\end{array}$ \\
\hline $8^{\mathrm{a}}$ & $23 d$ & 0.2 & 0.9 & 0.3 & 1.8 & & $78^{\mathrm{b}}$ & mother (premature menopause (28 years) \\
\hline 9 & $0.1 \mathrm{y}$ & 2 & & 3.6 & 2.2 & 272 & 955 & mother (hypospadias in each son of her 2 sisters) \\
\hline 10 & 0.1 y & 2.1 & & 3.2 & 2.4 & 176 & 630 & father (cryptorchidism) \\
\hline 11 & $0.1 \mathrm{y}$ & 0.1 & & 4.6 & 0.92 & 179 & 865 & mother (brother of cases 2 and 3) \\
\hline 12 & $0.3 y$ & 1.2 & & 0.9 & 1 & 590 & 1674 & father (hypospadias) \\
\hline 13 & 0.4 y & 1 & & 2.4 & 0.7 & 347 & 1129 & $\begin{array}{l}\text { mother (brother DSD, nephew hypospadias) } \\
\text { father (unilateral cryptorchidism and } 2 \text { meatus } \\
\text { urinarus in brothers) }\end{array}$ \\
\hline 14 & $5 y$ & & & 0.7 & 1 & 14 & 1136 & brother (hypospadias) \\
\hline 15 & $0.8 \mathrm{y}$ & 0.02 & & $<0.4$ & 0.6 & 175 & 1042 & father (cryptorchidism) \\
\hline 16 & $0.8 \mathrm{y}$ & $<0.05$ & & $<0.4$ & $<0.4$ & 253 & 1245 & mother (half brother of case 24) \\
\hline $17^{\mathrm{a}}$ & $1.5 \mathrm{y}$ & $<0.05$ & $<0.05$ & 1.7 & 45 & ND & & mother (DSD in uncle) \\
\hline 18 & $1.8 \mathrm{y}$ & & & $<0.4$ & $<0.4$ & 94 & 485 & father (hypospadias in brother) \\
\hline 19 & $3 y$ & $<0.07$ & & $<0.2$ & 0.47 & 77 & 1086 & father (hypospadias in brother) \\
\hline 20 & $3.5 \mathrm{y}$ & $<0.07$ & 3.3 & & ND & & & $\begin{array}{l}\text { father (infertility in one sister and in } \\
\text { paternal grandmother) }\end{array}$ \\
\hline 21 & $3.9 y$ & & & & 0.6 & 97 & 593 & $\begin{array}{l}\text { father (unilateral cryptorchidism } \\
\text { as in cousin) }\end{array}$ \\
\hline 22 & $7.6 y$ & & & & ND & 44 & 719 & brother (hypospadias) \\
\hline 23 & $10 y$ & 1.1 & 1.6 & $<0.2$ & 1.5 & ND & 37 & brother (left cryptorchidism) \\
\hline 24 & $13.6 y$ & 1.2 & & 0.9 & 0.5 & 217 & 64 & mother (half brother of case 16) \\
\hline 25 & $15 y$ & 10.3 & & 4.6 & 4.3 & 157 & 165 & mother (uncle of cases $2,3,11$ ) \\
\hline
\end{tabular}

${ }^{a}$ Genetic mutations (reference): case 5 SRY p.W98 C; case 7 GATA4 p.Gly221Arg (9); case 8 NR5A1 c.390delG (8); case 17 FOF2/ZFPM 2p.S402R (10) Consanguinity reported in case 23

Cases 2,3,11 are brothers and case 25 is their maternal uncle. Cases 16 and 24 has the same mother (see pedigree)

${ }^{\mathrm{b}}$ Age at assays similar except case 1 at $1.2 \mathrm{y}$, case 4 at $9 \mathrm{y}$, case 6 at $10 \mathrm{y}$, case 8 at $8.5 \mathrm{y}$

endocrinologist (22\% of the DSD and $27 \%$ of the anorchia) when premature menopause or infertility are included.

\section{Biological data}

The analysis of the biological data enables us 1) to define causes of DSD responsible for familial forms (androgen insensitivity, defects of testosterone synthesis, $5 \alpha$-reductase deficiency); 2) to evaluate the Leydig and tubular functions; and 3) to compare this function in the same family and also its evolution with time if the individuals are of different ages. By this approach congenital adrenal hyperplasia or insufficiency as well as other causes of familial DSD were excluded. The plasma concentrations of testosterone (basal and after hCG test), indicating normal secretion associated with normal plasma luteinizing hormone $(\mathrm{LH})$ concentrations during the first months, make the diagnoses of androgen insensitivity [16], defects of testosterone biosynthesis or Leydig cell hypoplasia less likely. Interestingly, the $7 / 13$ of the cases evaluated during the first 6 months of life with low basal testosterone concentrations included the 4 in the series with mutation and 3 brothers (See below). In addition, mutations in exons 1 
Table 3 Characteristics of 7 patients with familial form of anorchia

\begin{tabular}{|c|c|c|c|c|c|c|c|c|c|}
\hline \multirow[t]{2}{*}{ Case } & \multicolumn{2}{|c|}{ Testes at birth } & \multirow{2}{*}{$\begin{array}{l}\text { Age at first } \\
\text { evaluation }\end{array}$} & \multirow{2}{*}{$\begin{array}{l}\text { Testosterone } \\
(\mathrm{ng} / \mathrm{mL})\end{array}$} & \multirow[t]{2}{*}{ LH (IU/L) } & \multirow[t]{2}{*}{$\mathrm{FSH}(\mathrm{IU} / \mathrm{L})$} & \multirow{2}{*}{$\begin{array}{l}\text { Inhibin B } \\
\text { (pg/mL) }\end{array}$} & \multirow[t]{2}{*}{ AMH (pmol/L) } & \multirow[t]{2}{*}{ Parent (family history) } \\
\hline & Right & Left & & & & & & & \\
\hline 26 & $p$ & $\mathrm{np}$ & $1 d$ & ND & $<0,4^{\mathrm{b}}$ & $<0,4^{b}$ & und & 5 & mother and fetus sister (see Results) \\
\hline 27 & $p$ & $p$ & $1.3 y$ & und & 5.5 & 68 & und & 2.5 & mother (see Results) \\
\hline 28 & $\begin{array}{l}\text { torsion } \\
\text { at birth }\end{array}$ & $\begin{array}{l}\text { torsion } \\
\text { at birth }\end{array}$ & $3.2 y$ & 0.15 & $6^{b}$ & $34^{b}$ & ND & ND & $\begin{array}{l}\text { father (secondary infertility with } \\
\text { oligoasthenospermia) }\end{array}$ \\
\hline 29 & ND & ND & $2 y$ & und $^{a}$ & $<0,2^{b}$ & $18^{b}$ & ND & und & $\begin{array}{l}\text { father (increased basal plasma FSH } \\
\text { concentration }(12 \mathrm{IU} / \mathrm{L}) \text { at } 38 \mathrm{y})\end{array}$ \\
\hline 30 & ND & ND & $6.2 y$ & und $^{a}$ & 0.5 & 0.05 & und & und & mother (cryptorchidism in cousin) \\
\hline 31 & ND & & $8.2 y$ & ND & & 2.8 & und & und & father (cryptorchidism in son of sister) \\
\hline 32 & $\mathrm{np}$ & $\mathrm{np}$ & $13.6 y$ & 0.09 & 25 & 122 & ND & ND & mother (premature menopause at $28 \mathrm{y}$ ) \\
\hline
\end{tabular}

ND not determined, und undetectable

${ }^{\mathrm{a}} \mathrm{No}$ increase in testosterone after hCG test

${ }^{\mathrm{b}}$ Age at assays similar except case 26 at 0.8 y, 28 at 12.6, 29 at 6 y

and $2-8$ of the androgen receptor gene were excluded in 8 patients, including $1 / 2$ with increased plasma $\mathrm{AMH}$ concentrations [19]. These concentrations, as well as those of inhibin $\mathrm{B}$, provide information on the tubular function during childhood. They are undetectable in the patients with anorchia and in those with gonadal dysgenesis. Thus, in the patient carrying the $S R Y$ mutation, there was discordance between the 46,XY karyotype in utero and the absence of virilization of the external genitalia. The undetectable levels of testosterone and $\mathrm{AMH}$ in the amniotic fluid also excluded androgen insensitivity and suggested gonadal dysgenesis.

\section{Phenotypic variability}

We and other investigators have observed variable expression of the clinical phenotypes as well as incomplete penetrance among family members carrying the same pathogenic mutation. Although rare, phenotypically normal brothers, fathers and paternal uncles of patients carrying the same $S R Y$ have been described [11]. None of these mutations has been found by population screening of large populations of unaffected 46,XY men. Many cases of DSD may be are familial rather than sporadic, as sometimes the effect on the phenotype can be so mild that the unsuspecting clinician may not diagnose mildly affected individuals until a more severely affected family members seeks medical attention. Baetens et al. [26] reported an NR5A1 mutation in a proband with hypospadias and in his asymptomatic mother (regular menses at 30 years of age), maternal aunt (who had been diagnosed with primary ovarian insufficiency at 35), and maternal grandfather (who had been operated on for proximal hypospadias but spontaneously fathered the two girls). Camats et al. [27] suggested that the phenotypic variability may be a manifestation of the time-dependent deterioration of gonadal tissue and/or steroid secretion. In our study, one family included three brothers (cases 2, 3 and
11) who were evaluated in the neonatal period and had similar biological presentations, with normal plasma concentrations of inhibin B and $\mathrm{AMH}$ but low basal plasma testosterone concentrations. Their maternal uncle (case 25) also presented at 15 years of age with DSD and had normal adult concentrations of testosterone but developed azoospermia, despite initial normal inhibin B and AMH concentrations, suggesting testicular regression. Genomic sequencing may help to determine the source of this variability by revealing genetic modifiers that likely result from interactions between coding and regulatory variants resulting in an increased penetrance of rare pathogenic coding mutations [28].

We included patients with anorchia in this study because the familial occurrence of anorchia [2, 3,5] and its association with other anomalies including gonadal dysgenesis suggest a genetic origin, but the genetic cause remains unknown, except in one case, which was reported to carry an NR5A1 mutation [29]. The families of some patients with anorchia may include other individuals with pure or partial 46,XY gonadal dysgenesis. This has led to the hypothesis that anorchia is part of the clinical spectrum of 46,XY gonadal dysgenesis [7]. However, exploratory laparoscopy has suggested that at least some cases of anorchia are the result of prenatal testicular vascular accident associated with torsion during testicle descent [30].

We report a family history of reproductive problems in $6 / 25(24 \%)$ patients with DSD and in $2 / 7$ (29\%) patients with anorchia. Two fathers are secondarily azoospermic and two mothers presented with premature menopause, suggesting a deterioration of their gonadal tissue over time. A link between gonadal development and infertility is becoming more evident as our understanding of the genes involved in gonad formation increases. For example, mutations in NR5A1 cause DSD as well as male [31] and female infertility [8]. 


\section{Genetic analyses}

A mutation associated with the phenotype was found in 4/14 patients presenting with ambiguous genitalia. Barseghyan et al. [32] recently found that reported data suggest that $15 \%$ of $46, \mathrm{XY}$ gonadal dysgenesis cases are due to $S R Y$ mutations, $13 \%$ to mutations in NR5A1, 10-18\% to $M A P 3 K 1$ variants, and a few cases to other rare genetic causes. The risk of malignancy is estimated to be approximately $30 \%$ in $46, \mathrm{XY}$ individuals with DSD [33]. Among the 3 patients who underwent gonadectomies because of gonadal dysgenesis, two had gonadoblastoma and/or dysgerminoma, while the third operated on at 2 years of age had no tumor. This suggests that information to make an accurate diagnosis as well as information on the wider family members by the physician is of great importance. We did not perform this step, as it is sensitive in terms of the relationships and information sharing within the families.

\section{Study limitations}

The present study has limitations because it is retrospective. No biological data of the affected members are available. The link between the DSD or anorchia of the proband and the symptoms in his/her family is probable but not confirmed, except in $75 \%$ of families carrying the mutation. Other causes of premature menopause or infertility were not excluded, as only one mother shares the NR5A1 mutation with her son. We have no data on the infertility. Two fathers (of cases 4 and 28) were explored for secondary infertility, one of them has oligoasthernospermia. We retained cryptorchidism as a possible marker of familial form in 3 fathers (also present in a cousin in one case) and in one brother of the only patient of this series with consanguinity. Androgen insensitivity was excluded by the absence of mutation in only 8 patients, but the clinical-biological and evolutive (increase of the genital tubercle after testosterone administration) data make this diagnosis less likely. The exclusion of the diagnosis of $5 \alpha$-reductase deficiency was based on the normal testosterone to dihydrotestosterone ratio, except in 3 cases where a mutation was excluded. There have been instances reported in the littérature of affected individuals who did not meet this hormonal criteria [34].

\section{Conclusions}

This study is the first to demonstrate the high frequency of familial forms of 46,XY DSD and anorchia when premature menopause and male infertility are included. It also demonstrates the high variability of the expression of the phenotype within the families and the probable deterioration of fertility indicated by secondary sterility in two fathers and by premature menopause in two mothers. It poses the question of the risk of malignancy in the other affected members of the families, particularly in those with gonadal dysgenesis, as the collection of information within the families on this subject is difficult. The study also highlights the need to the physician to gather information on the fertility status of other members of the family. This could be important to identify familial cases, understand modes of transmission of the phenotype and eventually understand the genetic factors that are involved.

\section{Abbreviations \\ AMH: Anti-müllerian hormone; DSD: Disorders of sex development; FSH: Follicle stimulating hormone; hCG: Human chorionic gonadotropin; LH: Luteinising hormone; MRI: Magnetic resonance imaging}

\section{Acknowledgements}

The authors thank the following surgeons : Dr. Lottman (cases 1, 2, 3, 6, 11, $12,18,21,24,25,30)$, Dr. Lortat-Jacob (cases 4, 8, 14, 17, 20), Pr. NihoulFékété (case 4, 7) and Pr. Revillon (case 32), Hôpital Necker Enfants Malades, Paris; Dr. De Dreuzy (cases 9, 10 and 31) and Dr. Fouquet (case 26), Hôpital Bicêtre, Le Kremlin Bicêtre; Pr. Beurton (case 29), Hôpital Ambroise Paré, Boulogne Billancourt; Dr. Lababidi (cases 13 and 27), Hôpital de Villeneuve Saint Georges; Dr. Ait Ali Slimane (case 15), Clinique chirurgicale de Boulogne, Boulogne Billancourt.

We thank Pr. Jaubert, Department of Pathology and Pr. Brunelle and Dr. Roussel, Department of Pediatric Radiology, for the patients evaluated at Hôpital Necker Enfants Malades, Paris. We thank Dr. Philibert and Pr. Sultan, Hôpital Lapeyronie, Montpellier for the exclusion of mutations in the exons 1 and 2-8 of androgen receptor gene in 7 patients and in the gene of the $5 \mathrm{a}$ reductase in cases 11, 16 and 25, and Pr. Morel, Groupement Hospitalier Est, Bron, in one patient. The authors thank Françoise Valentin and Monique Pouillot for their technical help, Dr. Trivin, Service d'explorations fonctionnelles, Hôpital Necker Enfants Malades, Paris, and Dr. Brailly-Tabard, service de génétique moléculaire, pharmacogénétique et hormonologie, Le Kremlin Bicêtre for the hormonal profiling.

\section{Funding}

This work is supported by Laboratoire Lilly France, Projet Blanc Institut Pasteur/Assistance Publique-Hôpitaux de Paris 2011 PTR 415, and EuroDSD in the European Community's Seventh Framework Programme FP7/2007-2013 under grant 201444

\section{Availability of data and materials}

The data that support the findings of this study are available from the corresponding author upon reasonable request.

\section{Authors' contributions}

RB conceptualized and designed the study and drafted the manuscript; FPD collected and analysed the clinical data; $\mathrm{HL}$ collected and analysed the surgical data; SR collected and analysed the clinical data; JBT performed the genetic analyses; $A B$ performed the genetic analyses and contributed to the discussion; KmE designed the study and drafted the manuscript. All authors read and approved the final manuscript.

\section{Competing interests}

The authors declare that they have no competing interests.

Consent for publication

Not applicable.

\section{Ethics approval and consent to participate}

Written, informed consent was obtained from the children's parents. Evaluations included clinical and biological evaluations, chromosomal analysis, molecular biology analysis, surgery and participation to the study. All investigations were conducted according to the principles expressed in the Helsinki Declaration. The Ethical Review Committee (Comité de Protection des Personnes, lle de France IV) approved this study (IRB $n^{\circ}$ 00003835). Patient information was anonymized prior to analysis. 


\section{Author details}

'Fondation Ophtalmologique Adolphe de Rothschild and Université Paris Descartes, Paris, France. ${ }^{2}$ Assistance Publique-Hôpitaux de Paris, Hôpital Necker-Enfants Malades, Service de chirurgie viscérale pédiatrique, Paris, France. ${ }^{3}$ Human Developmental Genetics, Institut Pasteur, Paris, France.

Received: 22 November 2015 Accepted: 24 November 2016

Published online: 29 November 2016

\section{References}

1. Hughes IA, Houk C, Ahmed SF, Lee PA, Consensus Group LWPES, Consensus Group ESPE. Consensus statement on management of intersex disorders. Arch Dis Child. 2006:91:554-63.

2. Abeyaratne MR, Aherne WA, Scott JES. The vanishing testis. Lancet. 1969;2: 822-4.

3. Bobrow M, Gough MH. Bilateral absence of testes. Lancet. 1970;1:366.

4. Aynsley-Green A, Zachmann M, Illig R, Rampini S, Prader A. Congenital bilateral anorchia in childhood: a clinical, endocrine and therapeutic evaluation of twenty-one cases. Clin Endocrinol (Oxf). 1976;5:381-91.

5. Josso N, Briard ML. Embryonic testicular regression syndrome: variable phenotypic expression in siblings. J Pediatr. 1980;97:200-4.

6. Zenaty D, Dijoud F, Morel Y, Cabrol S, Mouriquand P, Nicolino M, et al. Bilateral anorchia in infancy: occurence of microphallus and the effect of testosterone treatment. J Pediatr. 2006:149:687-91.

7. Marcantonio SM, Fechner PY, Migeon CJ, Perlman EJ, Berkovitz GD. Embryonic testicular regression sequence: a part of the clinical spectrum of 46, XY gonadal dysgenesis. Am J Med Genet. 1994;49:1-5.

8. Lourenço D, Brauner R, Lin L, De Perdigo A, Weryha G, Muresan M, et al. Mutations in NR5A1 associated with ovarian insufficiency. N Engl J Med. 2009;360:1200-10.

9. Lourenco D, Brauner R, Rybczynska M, Nihoul-Fekete C, McElreavey K Bashamboo A. Loss-of-function mutation in GATA4 causes anomalies of human testicular development. Proc Natl Acad Sci U S A. 2011;108:1597-602.

10. Bashamboo A, Brauner R, Bignon-Topalovic J, Lortat-Jacob S, Karageorgou V, Lourenco D, et al. Mutations in the FOG2/ZFPM2 gene are associated with anomalies of human testis determination. Hum Mol Genet. 2014;23:3657-65.

11. Sarafoglou K, Ostrer H. Familial sex reversal: a review. J Clin Endocrino Metab. 2000;85:483-93.

12. Brauner R, Neve M, Allali S, Trivin C, Lottmann H, Bashamboo A, et al. Clinical, biological and genetic analysis of anorchia in 26 boys. PLoS ONE. 2011;6(8):e23292. doi:10.1371/journal.pone.0023292.

13. Bastian C, Muller J-B, Lortat-Jacob S, Nihoul-Fekete C, Bignon-Topalovic J, Mcelreavey K, et al. Genetic mutations and somatic anomalies in association with 46,XY gonadal dysgenesis. Fertil Steril ${ }^{\oplus}$. 2015;103:1297-304.

14. Nelson LM. Primary ovarian insufficiency. N Engl J Med. 2009;360:606-14

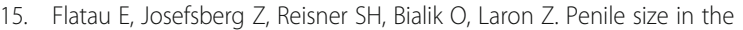
newborn infant. J Pediatr. 1975;87:663-4.

16. Bouvattier C, Carel J-C, Lecointre C, David A, Sultan C, Bertrand A-M, et al. Postnatal changes of $\mathrm{T}, \mathrm{LH}$, and FSH in $46, \mathrm{XY}$ infants with mutations in the AR gene. J Clin Endocrinol Metab. 2002;87:29-32.

17. Andersson AM, Juul A, Petersen JH, Muller J, Groome NP, Skakkebaek NE. Serum inhibin $B$ in healthy pubertal and adolescent boys: relation to age, stage of puberty, and follicle-stimulating hormone, luteinizing hormone, testosterone, and estradiol levels. J Clin Endocrinol Metab. 1997;82:3976-81.

18. Andersson AM, Toppari J, Haavisto AM, Petersen JH, Simell T, Skakkebaek NE. Longitudinal reproductive hormone profiles in infants: peak of inhibin B levels in infant boys exceeds levels in adult men. J Clin Endocrinol Metab. 1998;83:675-81.

19. Rey RA, Belville C, Nihoul-Fekete C, Michel-Calemard L, Forest MG, Lahlou N, et al. Evaluation of gonadal function in 107 intersex patients by means of serum antimullerian hormone measurement. J Clin Endocrinol. 1999;84:627-31.

20. McElreavy K, Vilain E, Abbas N, Costa JM, Souleyreau N, Kucheria K, et al. XY sex reversal associated with a deletion 5' to the SRY "HMG box" in the testis-determining region. Proc Natl Acad Sci U S A. 1992;89:11016-20.

21. Mallet D, Bretones P, Michel-Calemard L, Dijoud F, David M, Morel Y. Gonadal dysgenesis without adrenal insufficiency in a 46, XY patient heterozygous for the nonsense C16X mutation: a case of SF1 haploinsufficiency. J Clin Endocrinol Metab. 2004;89:4829-32.

22. Vinci G, Anjot MN, Trivin C, Lottmann H, Brauner R, Bashamboo A, et al. An analysis of the genetic factors involved in testicular descent in a cohort of 14 male patients with anorchia. J Clin Endocrinol Metab. 2004;89:6282-5.
23. Pearlman A, Loke J, Le Caignec C, White S, Chin L, Friedman A, et al. Mutations in MAP3K1 cause 46, XY disorders of sex development and implicate a common signal transduction pathway in human testis determination. Am J Hum Genet. 2010:87:898-904.

24. El Houate B, Rouba H, Sibai H, Barakat A, Chafik A, Chadli E, et al. Novel mutations involving the INSL3 gene associated with cryptorchidism. J Urol. 2007;77(5):947-51.

25. El Houate B, Rouba H, Imken L, Sibai H, Chafik A, Boulouiz R, et al. No association between T222P/LGR8 mutation and cryptorchidism in the Moroccan population. Horm Res. 2008;70(4):236-9.

26. Baetens D, Mladenov W, Delle Chiaie B, Menten B, Desloovere A, lotava V, et al. Extensive clinical, hormonal and genetic screening in a large consecutive series of 46,XY neonates and infants with atypical sexual development. Orphanet J Rare Dis. 2014;9:209. doi:10.1186/s13023-014-0209-2.

27. Camats N, Pandey AV, Fernández-Cancio M, Andaluz P, Janner M, Torán N et al. Ten novel mutations in the NR5A1 gene cause disordered sex development in 46, XY and ovarian insufficiency in 46, XX individuals. J Clin Endocrinol Metab. 2012;97:E1294-306. doi:10.1210/jc.2011-3169. Epub2012May.

28. Lappalainen T, Montgomery SB, Nica AC, Dermitzakis ET. Epistatic selection between coding and regulatory variation in human evolution and disease. Am J Hum Genet. 2011:89:459-63.

29. Philibert P, Zenaty D, Lin L, Soskin S, Audran F, Leger J, et al. Mutational analysis of steroidogenic factor 1 (NR5a1) in 24 boys with bilateral anorchia: a French collaborative study. Hum Reprod. 2007;22:3255-61.

30. Smith NM, Byard RW, Bourne AJ. Testicular regression syndrome-a pathological study of 77 cases. Histopathology. 1991;19:269-72.

31. Bashamboo A, Ferraz-de-Souza B, Lourenco D, Lin L, Sebire NJ, Montjean D, et al. Human male infertility associated with mutations in NR5A1 encoding steroidogenic factor 1. Am J Hum Genet. 2010;87:505-12.

32. Barseghyan H, Délot E, Vilain E. New genomic technologies: an aid for diagnosis of disorders of sex development. Horm Metab Res. 2015;47(5): 312-20. doi:10.1055/s-0035-1548831. Epub 2015 May 13.

33. Kingsbury AC, Frost F, Cookson WO. Dysgerminoma, gonadoblastoma, and testicular germ cell neoplasia in phenotypically female and male siblings with 46 XY genotype. Cancer. 1987;59:288-91.

34. Cheng J, Lin R, Zhang W, et al. Phenotype and molecular characteristics in 45 Chinese children with 5a-reductase type 2 deficiency from South China. Clin Endocrinol. 2015:83:518-26.

\section{Submit your next manuscript to BioMed Central and we will help you at every step:}

- We accept pre-submission inquiries

- Our selector tool helps you to find the most relevant journal

- We provide round the clock customer support

- Convenient online submission

- Thorough peer review

- Inclusion in PubMed and all major indexing services

- Maximum visibility for your research

Submit your manuscript at www.biomedcentral.com/submit
) Biomed Central 